\title{
Serum Concentrations of Adipocyte Fatty Acid Binding Protein in Patients with Anorexia Nervosa
}

\author{
D. HALUZÍKOVÁ ${ }^{1,2}$, I. DOSTÁLOVÁ ${ }^{2}$, P. KAVÁLKOVÁ ${ }^{2}$, T. ROUBÍČEK ${ }^{2}$, M. MRÁZ ${ }^{2}$, \\ H. PAPEŽOVÁ ${ }^{3}$, M. HALUZÍK ${ }^{2}$ \\ ${ }^{1}$ Department of Sports Medicine, ${ }^{2}$ Third Department of Medicine and ${ }^{3}$ Department of Psychiatry, \\ First Faculty of Medicine and General University Hospital, Prague, Czech Republic
}

Received April 12, 2008

Accepted May 27, 2008

On-line July 25, 2008

\section{Summary}

Serum adipocyte fatty acid-binding protein (FABP) concentrations are linked to human obesity and other features of metabolic syndrome. Whether FABP associates with metabolic alterations in chronic malnutrition is unknown. In the present study, we measured fasting serum levels of FABP, leptin, soluble leptin receptor, adiponectin, resistin, C-reactive protein (CRP), insulin, glucose, cholesterol and triglycerides in 19 patients with a restrictive type of anorexia nervosa (AN) and in 16 healthy agematched control women (C). Body mass index, serum leptin, and CRP concentrations were significantly lower, while serum adiponectin and soluble leptin receptor levels were significantly higher in AN relative to C group. Serum insulin, glucose, cholesterol and triglyceride levels did not differ between the groups studied. Serum FABP levels were unchanged in patients with $\mathrm{AN}$ and were not related to any of parameters studied. We conclude that, in contrast to patients with obesity where FAPB is a prominent marker of metabolic alterations, chronic malnutrition in AN does not significantly affect its serum levels.

\section{Key words}

Adipocyte fatty acid binding protein - Anorexia nervosa • Malnutrition • Adipokines • Biochemical parameters

\section{Corresponding author}

M. Haluzík, Third Department of Medicine, First Faculty of Medicine, U Nemocnice 1, 12800 Prague 2, Czech Republic. E-mail: mhalu@If1.cuni.cz

\section{Introduction}

Fatty acid-binding proteins are cytoplasmic proteins with highly specific tissue distribution that mediate intracellular fatty acid trafficking and exert a variety of effects in metabolic regulations (Coe and Bernlohr 1998, Hertzel and Bernlohr 2000, Boord et al. 2002, Chmurzynska 2006).

Adipocyte fatty acid-binding protein (FABP) is one of the most abundant proteins in mature adipocytes (Makowski and Hotamisligil 2004). Although traditionally considered an intracellular cytosolic protein, it is present in human circulation (Xu et al. 2006, Karpíšek et al. 2007, Xu et al. 2007). Circulating FABP concentrations are increased in patients with obesity and/or metabolic syndrome and strongly positively correlate with body adiposity ( $\mathrm{Xu}$ et al. 2006) and with various features of metabolic syndrome including insulin sensitivity variables (Xu et al. 2006, Haluzík et al. 2008). Experimental studies have shown that both the knockout of adipocyte fatty acid-binding protein gene or its inhibition by a small-molecule inhibitor improved insulin sensitivity and atherosclerosis in mice (Maeda et al. 2005, Furuhashi et al. 2007).

Here we explored whether circulating FABP levels are altered by chronic malnutrition in humans. We selected severely malnourished patients with a restrictive type of AN as a model of extreme state of chronic negative energy balance. The restrictive form of AN represents a bordering example of psychosomatic-based malnutrition induced by chronically decreased food intake caused by inappropriate fear of obesity and distorted body 
image (1994 Diagnostic and Statistical Manual of Mental Disorders (DSM-IV). 4th ed. Washington, DC: American Psychiatric Association). AN is associated with severe alterations of lipid and carbohydrate metabolism, including increased lipolysis in adipose tissue (Barták et al. 2004, Nedvídková et al. 2004, Křrižová et al. 2007). Whether FABP associates with abnormal energy metabolism in patients with AN is unknown.

To our best knowledge, FABP has not been studied in patients with AN. Here we tested the hypothesis that altered circulating FABP levels may contribute to the etiopathogenesis and/or some of the metabolic changes in patients with AN. To this end, we measured fasting serum concentrations of FABP in patients with a restrictive type of AN and in healthy normal-weight women and studied the relationship of this factor to nutritional status and selected endocrine and biochemical parameters.

\section{Patients and Methods}

\section{Study subjects}

Nineteen previously untreated female patients with restrictive subtype of AN (age 25.0 1.34 years; body mass index (BMI) $15.9 \pm 0.33 \mathrm{~kg} / \mathrm{m}^{2}$ ) and sixteen age- and sex-matched healthy controls $(24.7 \pm 0.59$ years; $22.9 \pm 0.41 \mathrm{~kg} / \mathrm{m}^{2}$ ) were included in the study. The diagnosis of eating disorder was based on the Diagnostic Statistical Manual IV diagnostic system (American Psychiatric Association, 1994). A clinical evaluation of the patients was performed by an experienced psychiatrist. The Structured Clinical Interview MINI 5.0 was used for diagnostic assessment of patients. None of the studied subjects suffered from diabetes mellitus, thyroid disorder, and/or acute infectious disease. All subjects included in the study were non-smokers, had no allergies, and had been free of medication for at least three months prior to the study. Healthy normal-weight women had no history of obesity or malnutrition, hypertension, gastrointestinal disease, eating disorder or other psychiatric disorder. Blood tests confirmed normal blood count, liver and renal functions. All patients with AN had amenorrhea, whereas all healthy women had regular menstrual cycle. All subjects were asked to fast and drink only water on the night prior to the study. Written informed consent was provided by all participants before being enrolled in the study. The study was approved by the Human Ethical Review Committee, First Faculty of Medicine and General University Hospital,
Prague, Czech Republic, and was performed in accordance with the guidelines proposed in the Declaration of Helsinki.

\section{Anthropometric examination and blood sampling}

All patients were examined at a basal state before the beginning of any treatment. All subjects were measured and weighted. Blood samples for FABP, resistin, adiponectin, leptin, leptin receptor, insulin and biochemical parameters measurements were withdrawn between 0700 and $0800 \mathrm{~h}$ after $12 \mathrm{~h}$ of overnight fasting.

\section{Hormonal and biochemical assays}

Serum FABP concentrations were measured by a commercial ELISA kit (BioVendor, Brno, Czech Republic). The sensitivity was $0.1 \mathrm{ng} / \mathrm{ml}$, and the intraand interassay variability was 3.9 and $5.1 \%$, respectively. Serum insulin concentrations were measured by commercial RIA kit (Cis Bio International, Gif-surYvette, France). Sensitivity was $2.0 \mu \mathrm{IU} / \mathrm{ml}$, and the intra- and interassay variability was 4.2 and $8.8 \%$, respectively. Serum leptin concentrations were measured by commercial ELISA kit (BioVendor, Brno, Czech Republic). Sensitivity was $0.12 \mathrm{ng} / \mathrm{ml}$, and the intra- and interassay variability was 1.7 and $8.0 \%$, respectively. Serum soluble leptin receptor concentrations were measured by commercial ELISA kit (BioVendor, Brno, Czech Republic). Sensitivity was $0.4 \mathrm{U} / \mathrm{ml}$, and the intraand interassay variability was 4.4 and $7.2 \%$, respectively. Serum adiponectin concentrations were measured by commercial ELISA kit (BioVendor, Brno, Czech Republic). Sensitivity was $1.5 \mathrm{ng} / \mathrm{ml}$, and the intra- and interassay variability was 4.8 and $8.3 \%$, respectively. Serum resistin concentrations were measured by commercial ELISA kit (BioVendor, Brno, Czech Republic). Sensitivity was $0.2 \mathrm{ng} / \mathrm{ml}$, and the intra- and interassay variability was 3.1 and $6.5 \%$, respectively. Serum levels of biochemical parameters were measured by standard laboratory methods.

\section{Statistical analysis}

The statistical analysis was performed on SigmaStat software (Jandel Scientific, San Rafael, CA). Results are expressed as mean \pm S.E.M. Unpaired $t$ test or Mann-Whitney test was used for comparison of groups as appropriate. The correlations between the values were estimated by Spearman correlation test. $\mathrm{P}<0.05$ value denoted statistical significance. 


\section{Results}

Anthropometric characteristics of study subjects

The study groups were age-matched. Patients with a restrictive type of AN were extremely malnourished as evidenced by severely decreased BMI (Table 1).

Serum levels of hormonal and biochemical parameters: comparison of AN and normal-weight women

Fasting serum glucose, insulin, glycated hemoglobin, total cholesterol and triglycerides did not significantly differ between the groups studied. Fasting serum leptin and C-reactive protein (CRP) levels were markedly reduced in AN group, whereas fasting serum adiponectin and soluble leptin receptor levels were significantly increased in patients with AN relative to $\mathrm{C}$ group. Fasting serum resistin did not significantly differ between $\mathrm{AN}$ and $\mathrm{C}$ group. Fasting serum FABP levels did not significantly differ between both groups (Table 1).

\section{Relationship of FABP with other studied parameters}

The relationship of FABP with other studied parameters was calculated both in the combined population of both groups (Table 2) and separately for each group (data not shown). Serum FABP was not related to any of other parameters studied, including BMI, leptin, leptin receptor, resistin, adiponectin, insulin, CRP, total cholesterol, HDL-cholesterol, LDLcholesterol, triglycerides and glucose regardless whether analyzed in combined population or in the two groups separately.

\section{Discussion}

The most important finding of the present study is that marked chronic malnutrition with severely decreased body fat content fails to affect serum levels of FABP in patients with AN. Previous human studies clearly showed that circulating FABP is strongly related to body weight, body adiposity, and features of metabolic syndrome in obese subjects (Xu et al. 2006, Cabré et al. 2007, Haider et al. 2007, Xu et al. 2007, Haluzík et al. 2008). Here we show, in contrast to studies in obese subjects, that the relationship of circulating FABP with body weight and metabolic status is abolished in malnourished patients with AN. These findings might be explained in two ways. Firstly, the disrupted relationship of FABP with anthropometric, endocrine and metabolic
Table 1. Anthropometric, hormonal and biochemical characteristics of control group of normal-weight healthy women and patients with anorexia nervosa.

\begin{tabular}{|c|c|c|}
\hline & $\begin{array}{l}\text { Controls } \\
(n=16)\end{array}$ & $\begin{array}{c}\text { Anorexia } \\
\text { Nervosa } \\
(n=19)\end{array}$ \\
\hline Age (years) & $24.7 \pm 0.59$ & $25.0 \pm 1.34$ \\
\hline $\begin{array}{l}\text { Body mass index } \\
\left(\mathrm{kg} / \mathrm{m}^{2}\right)\end{array}$ & $22.9 \pm 0.41$ & $15.9 \pm 0.33^{*}$ \\
\hline $\begin{array}{l}\text { Fasting insulin } \\
(\mu I U / m l)\end{array}$ & $14.3 \pm 1.40$ & $12.0 \pm 0.99$ \\
\hline $\begin{array}{l}\text { Fasting glucose } \\
\text { (mmol/l) }\end{array}$ & $4.1 \pm 0.25$ & $3.8 \pm 0.06$ \\
\hline$H b A l c(\%)$ & $3.4 \pm 0.14$ & $3.2 \pm 0.11$ \\
\hline $\begin{array}{l}\text { Total cholesterol } \\
(\mathrm{mmol} / \mathrm{l})\end{array}$ & $4.3 \pm 0.26$ & $5.2 \pm 0.31$ \\
\hline $\begin{array}{l}\text { Triglycerides } \\
(\mathrm{mmol} / \mathrm{l})\end{array}$ & $1.1 \pm 0.08$ & $1.02 \pm 0.17$ \\
\hline $\begin{array}{l}\text { C-reactive } \\
\text { protein }(\mathrm{mg} / \mathrm{l})\end{array}$ & $3.2 \pm 1.15$ & $0.9 \pm 0.65^{*}$ \\
\hline $\begin{array}{l}\text { Serum leptin } \\
(\mathrm{ng} / \mathrm{ml})\end{array}$ & $9.6 \pm 1.43$ & $1.5 \pm 0.31^{*}$ \\
\hline $\begin{array}{l}\text { Serum resistin } \\
(\mathrm{ng} / \mathrm{ml})\end{array}$ & $5.6 \pm 0.51$ & $4.9 \pm 0.59$ \\
\hline $\begin{array}{l}\text { Serum } \\
\text { adiponectin } \\
(\mu \mathrm{g} / \mathrm{ml})\end{array}$ & $19.9 \pm 2.29$ & $36.5 \pm 4.33 *$ \\
\hline $\begin{array}{l}\text { Soluble leptin } \\
\text { receptor }(\mathrm{U} / \mathrm{ml})\end{array}$ & $29.8 \pm 2.86$ & $40.2 \pm 2.72 *$ \\
\hline$F A B P(n g / m l)$ & $16.7 \pm 1.51$ & $15.4 \pm 1.77$ \\
\hline
\end{tabular}

Values are means \pm S.E.M. Statistical significance is from unpaired t-test or Mann-Whitney test as appropriate. ${ }^{*} \mathrm{p}<0.05$ vs. controls. HbA1c - glycosylated hemoglobin; FABP - adipocyte fatty acid-binding protein.

parameters is associated with chronic malnutrition and might contribute to metabolic alterations of patients with AN. Secondly, local production of FABP per unit of fat in AN patients might be increased relative to healthy subjects thus compensating for decreased total body fat content and/or FABP might be produced by different tissues in AN patients. Both hypotheses require further testing including the measurement of local FABP levels in adipose tissue of patients with AN.

Among other functions, FABP appears to be an important regulator of lipolysis. It was previously found that adipocytes from FABP-null mice have markedly 
Table 2. Relationship of adipocyte fatty acid binding protein (FABP) with anthropometric, biochemical and hormonal parameters calculated in a combined population of normal-weight healthy women and patients with anorexia nervosa $(n=35)$.

\begin{tabular}{|c|c|c|c|c|c|c|c|c|c|c|c|c|c|}
\hline & & $\sum_{M}^{E}$ & 竞 & 产 & 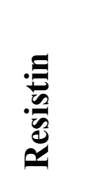 & $\stackrel{2}{\frac{2}{2}}$ & 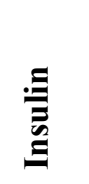 & $\hat{\bar{u}}$ & $\begin{array}{l}\overline{0} \\
\frac{0}{0} \\
\frac{0}{0} \\
\frac{0}{0}\end{array}$ & 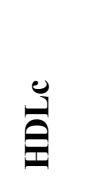 & $\stackrel{\mathfrak{d}}{\mathrm{U}}$ & $\underset{H}{U}$ & 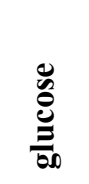 \\
\hline \multirow[t]{2}{*}{$F A B P$} & $r$ & 0.056 & 0.131 & 0.028 & 0.241 & -0.017 & 0.251 & 0.280 & 0.181 & 0.002 & 0.634 & -0.066 & 0.035 \\
\hline & $p$ & 0.758 & 0.467 & 0.899 & 0.163 & 0.921 & 0.217 & 0.185 & 0.473 & 0.996 & 0.091 & 0.830 & 0.888 \\
\hline
\end{tabular}

Data are correlation coefficients and their statistical significance is from Spearman Correlation Test. FABP - adipocyte fatty acid-binding protein; BMI - body mass index; LepR - leptin receptor; CRP - C-reactive protein; HDLc - high density lipoprotein cholesterol; LDLC low density lipoprotein cholesterol; TG - triglycerides.

reduced efficiency of lipolysis (Coe et al. 1999, Scheja et al. 1999) and exhibit reduced fatty acid release, suggesting that FABP mediates efflux of fatty acids from adipocytes (Baar et al. 2005, Xu et al. 2006). We have previously shown that patients with AN have higher rate of lipolysis relative to healthy women (Barták et al. 2004). It is tempting to speculate that local alterations in FABP levels in adipose tissue of patients with AN might be responsible for this metabolic abnormality.

Further factors characteristic for chronic malnutrition might influence the circulating levels of FABP. It has been previously shown that the strong relationship of FABP with parameters of metabolic syndrome is lacking in obese children (Reinehr et al. 2007). It is thus possible that the activity of FABP depends on the activity of gonadal axis that is severely suppressed in patients with AN.
In conclusion, we demonstrated that circulating levels of FABP in patients with a restrictive type of AN are unchanged relative to normal-weight women and are not related to body weight, circulating leptin, resistin, adiponectin, CRP, insulin, glucose, cholesterol and triglyceride levels. Further studies focused on local FABP levels in adipose tissue of anorectic patients need to be performed to unravel whether local alterations in FABP production in adipose tissue are responsible for this finding.

\section{Conflict of Interest}

There is no conflict of interest.

\section{Acknowledgements}

Supported by MZOVFN2005 and IGA 8302-5.

\section{References}

BAAR RA, DINGFELDER CS, SMITH LA, BERNLOHR DA, WU C, LANGE AJ, PARKS EJ: Investigation of in vivo fatty acid metabolism in AFABP/aP2(-/-) mice. Am J Physiol 288: E187-E193, 2005.

BARTÁK V, VYBÍRAL S, PAPEŽOVÁ H, DOSTÁLOVÁ I, PACÁK K, NEDVÍDKOVÁ J: Basal and exerciseinduced sympathetic nervous activity and lipolysis in adipose tissue of patients with anorexia nervosa. Eur $J$ Clin Invest 34: 371-377, 2004.

BOORD JB, FAZIO S, LINTON MF: Cytoplasmic fatty acid-binding proteins: emerging roles in metabolism and atherosclerosis. Curr Opin Lipidol 13: 141-147, 2002.

CABRÉ A, LÁZARO I, GIRONA J, MANZANARES JM, MARIMÓN F, PLANA N, HERAS M, MASANA L: Fatty acid binding protein 4 is increased in metabolic syndrome and with thiazolidinedione treatment in diabetic patients. Atherosclerosis 195: e150-158, 2007.

COE NR, BERNLOHR DA: Physiological properties and functions of intracellular fatty acid-binding proteins. Biochim Biophys Acta 1391: 287-306, 1998.

COE NR, SIMPSON MA, BERNLOHR DA: Targeted disruption of the adipocyte lipid-binding protein (aP2 protein) gene impairs fat cell lipolysis and increases cellular fatty acid levels. J Lipid Res 40: 967-972, 1999. 
FURUHASHI M, TUNCMAN G, GÖRGÜN CZ, MAKOWSKI L, ATSUMI G, VAILLANCOURT E, KONO K, BABAEV VR, FAZIO S, LINTON MF, SULSKY R, ROBL JA, PARKER RA, HOTAMISLIGIL GS: Treatment of diabetes and atherosclerosis by inhibiting fatty-acid-binding protein aP2. Nature. 447: 959-965, 2007.

HAIDER DG, SCHINDLER K, BOHDJALIAN A, PRAGER G, LUGER A, WOLZT M, LUDVIK B: Plasma adipocyte and epidermal fatty acid binding protein is reduced after weight loss in obesity. Diabetes Obes Metab 9: 761-763, 2007.

HALUZÍK M, ANDERLOVÁ K, DOLEŽAlOVÁ R, ADAMÍKOVÁ A, HALUZÍKOVÁ D, HOUSOVÁ J, SVAČINA S, HALUZÍK M: Serum adipocyte fatty acid binding protein levels in patients with type 2 diabetes mellitus and obesity: the influence of fenofibrate treatment. Physiol Res 58: 93-99, 2008.

HERTZEL AV, BERNLOHR DA: The mammalian fatty acid-binding protein multigene family: molecular and genetic insights into function. Trends Endocrinol Metab 11: 175-180, 2000.

CHMURZYŃSKA A: The multigene family of fatty acid-binding proteins (FABPs): function, structure and polymorphism. J Appl Genet 47: 39-48, 2006.

KARPÍŠEK M, STEJSKAL D, KOTOLOVÁ H, KOLLÁR P, JANOUTOVÁ G, OCHMANOVÁ R, ČÍŽEK L, HORÁKOVÁ D, YAHIA RB, LICHNOVSKÁ R, JANOUT V: Treatment with atorvastatin reduces serum adipocyte-fatty acid binding protein value in patients with hyperlipidaemia. Eur J Clin Invest 37: 637-642, 2007.

KŘÍŽOVÁ J, DOLINKOVÁ M, LACINOVÁ Z, SULEK S, DOLEŽALOVÁ R, HOUSOVÁ J, KRAJÍČKOVÁ J, HALUZÍKOVÁ D, BOŠANSKÁ L, PAPEŽOVÁ H, HALUZÍK M: Adiponectin and resistin gene polymorphisms in patients with anorexia nervosa and obesity and its influence on metabolic phenotype. Physiol Res 57: 539-546, 2008.

MAEDA K, CAO H, KONO K, GORGUN CZ, FURUHASHI M, UYSAL KT, CAO Q, ATSUMI G, MALONE H, KRISHNAN B, MINOKOSHI Y, KAHN BB, PARKER RA, HOTAMISLIGIL GS: Adipocyte/macrophage fatty acid binding proteins control integrated metabolic responses in obesity and diabetes. Cell Metab 1: 107119, 2005.

MAKOWSKI L, HOTAMISLIGIL GS: Fatty acid binding proteins - the evolutionary crossroads of inflammatory and metabolic responses. J Nutr 134: 2464S-2468S, 2004.

NEDVÍDKOVÁ J, DOSTÁLOVÁ I, BARTÁK V, PAPEŽOVÁ H, PACÁK K: Increased subcutaneous abdominal tissue norepinephrine levels in patients with anorexia nervosa: an in vivo microdialysis study. Physiol Res 53 : 409-413, 2004.

REINEHR T, STOFFEL-WAGNER B, ROTH CL: Adipocyte fatty acid-binding protein in obese children before and after weight loss. Metabolism 56: 1735-1741, 2007.

SCHEJA L, MAKOWSKI L, UYSAL KT, WIESBROCK SM, SHIMSHEK DR, MEYERS DS, MORGAN M, PARKER RA, HOTAMISLIGIL GS: Altered insulin secretion associated with reduced lipolytic efficiency in aP2-/- mice. Diabetes 48: 1987-1994, 1999.

XU A, WANG Y, XU JY, STEJSKAL D, TAM S, ZHANG J, WAT NM, WONG WK, LAM KS: Adipocyte fatty acidbinding protein is a plasma biomarker closely associated with obesity and metabolic syndrome. Clin Chem $\mathbf{5 2}$ : 405-413, 2006.

XU A, TSO AW, CHEUNG BM, WANG Y, WAT NM, FONG CH, YEUNG DC, JANUS ED, SHAM PC, LAM KS: Circulating adipocyte-fatty acid binding protein levels predict the development of the metabolic syndrome: a 5year prospective study. Circulation 115: 1537-1543, 2007. 